\title{
The long-term storage of blood for transfusion using an improved container for freezing the red cells in liquid nitrogen
}

\author{
W. J. JENKINS AND J. BLAGDON
}

From the North-East Metropolitan Regional Blood Transfusion Centre, Crescent Drive, Brentwood, Essex

sYNOPSIS Considerable experience has been gained in the operation of a bank of blood frozen in liquid nitrogen. The procedure for freezing and recovering the red cells is, in principle, that described by Krijnen, Kuivenhoven, and de Wit (1970). An improved metal freezing container offers greater freedom from liquid nitrogen leaks and hence, bacterial contamination. Over 500 units of blood have been preserved and used for transfusions without mishap, and many advantages are seen in this relatively economical method for the long-term storage of blood.

There is growing realization of the advantages to be gained from the long-term storage of blood for transfusion. An almost indefinite storage time is now possible by the use of liquid nitrogen employing either the method developed by Krijnen, de Wit, Kuivenhoven, Loos, and Prins (1964) or by Rowe, Eyster, and Kellner (1968). With enthusiastic help from Dr Krijnen, this transfusion centre has established a frozen blood bank from which 553 units of blood have, so far, been recovered for 209 successful transfusions. All renal dialysis patients within our region can now receive frozen/recovered blood.

Initial experience with equipment kindly supplied by Dr Krijnen and described by Krijnen et al (1970) caused concern because the aluminium container used for storage in liquid nitrogen is constructed in two parts. An elaborate screw-cap neck is pressed into the body of the canister with a rubber ' $O$ ' ring seal. There is always the danger that liquid nitrogen will leak at this joint with consequent danger of greatly increased pressure within the container when it is warmed, thus presenting the risk of explosion or of bacterial contamination during the recovery procedure.

\section{Modifications to Krijnen's Technique}

The authors have secured a supply of extruded aluminium canisters of one-piece construction with

${ }^{1}$ Part of this work was carried out with the aid of a grant from the Department of Health and Social Security through the Laboratory Equipment and Methods Advisory Group.

Received for publication 28 June 1971. a spun neck and rolled-over lip, coated on the outer surface with white lacquer. ${ }^{2}$ The dimensions are given in Figure 1.

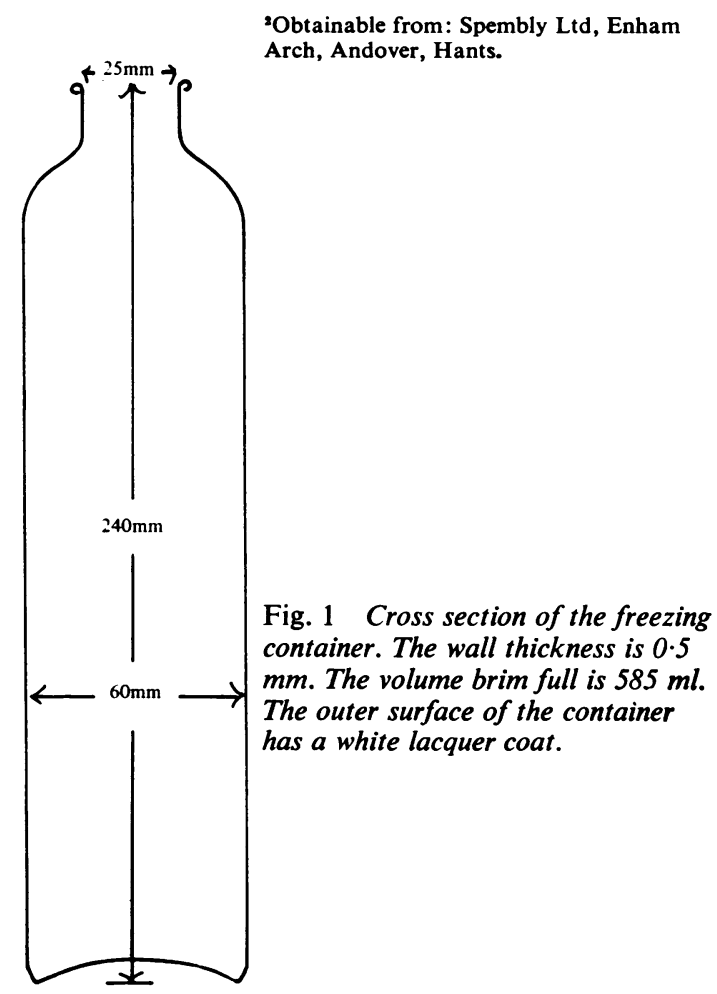


New canisters are prepared for use by washing in a non-caustic detergent solution (RBS 257) at $50^{\circ} \mathrm{C}$ for one hour with agitation. They are rinsed with $1 \%$ acetic acid in distilled water and six times with pyrogen-free distilled water. The outer coating of lacquer is 'fixed' by baking the canisters in a hot air oven at $140^{\circ} \mathrm{C}$ for two hours. Two $\mathrm{ml}$ of freshly distilled pyrogen-free distilled water is dispensed into each canister which is then stoppered with a Suba seal no. 57 rubber closure. The neck of the canister and the closure are coated with a film of glycerol/phenol mixture as described by Sherwin (1956) before turning the skirt of the closure over the neck and fixing firmly with a ring of insulated copper wire. The closure is covered with a viscap and autoclaved at $121^{\circ} \mathrm{C}$ for 30 minutes (Fig. 2).

Attempts to dry sterilize the canisters at $160^{\circ} \mathrm{C}$ for one hour as described by Krijnen et al (1970) were unsuccessful in our hands because the rubber closures degraded at this temperature.

Filling the containers with blood previously glycerolized in a plastic bag, emptying the containers, and the wash process follow the procedures already

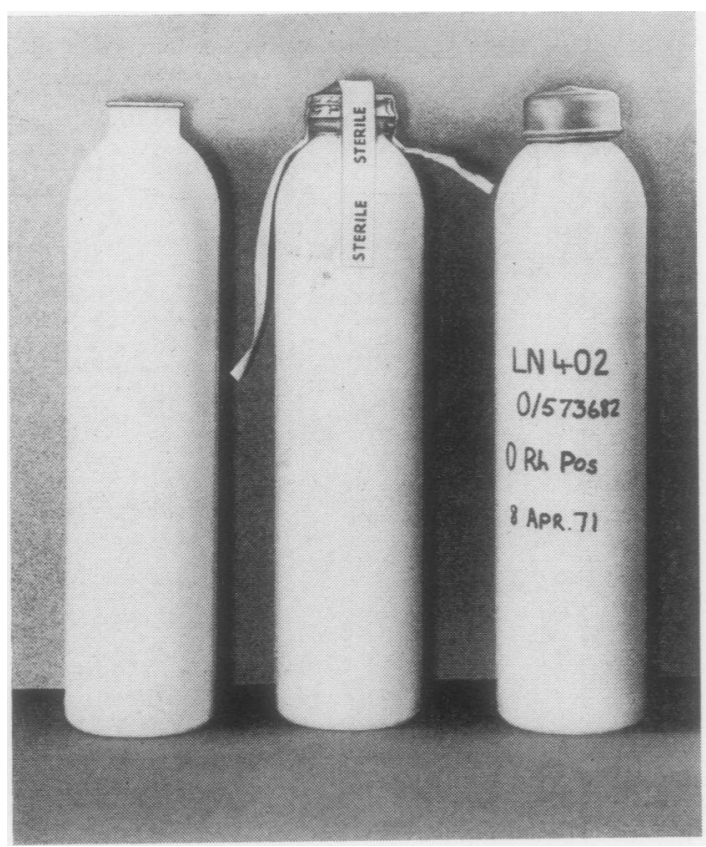

Fig. 2 The container on the left is as received from the manufacturer. The middle container has been sealed and autoclaved ready to be filled with the glycerolized red cell suspension. The container on the right has been filled, labelled, and has the outer rubber cap in place ready for freezing.

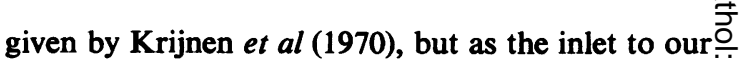
container offers a larger area for needle piercing, $\stackrel{\vec{\Rightarrow}}{\vec{\Rightarrow}}$ there is less likelihood of cutting into earlier punc-? tures when recovering the blood.

After filling the surface of the closure is coated $\frac{\bar{v}}{\bar{N}}$ with the glycerol/phenol mixture and covered with? an additional rubber cap (Fig. 2).

Leak testing carried out with 50 trial containers showed minor nitrogen vapour leaks on two occa- $\overrightarrow{0}$ sions represented by pressures at room temperature of about 2 in. of water. No liquid nitrogen leaks $\vec{\omega}$ were experienced.

No organisms were grown during sterility checkso carried out in the Public Health Laboratory Service N from spore strips placed in the containers before autoclaving and by cultures of whole units of blood after processing.

IMPURITIES IN THE ALUMINIUM (BY EMISSION SPECTROGRAPHY)

A number of canisters were submitted to the Department of Health and Social Security for chemical tests on the aluminium canister and contained water after sterilization.

The following substances were reported and are within accepted levels for transfusion purposes:

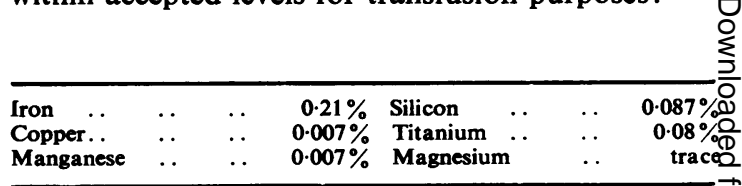

$\mathrm{Zn}, \mathrm{Ni}, \mathrm{Cr}, \mathrm{As}, \mathrm{Pb}$, and $\mathrm{Sn}$ were not detected.

IMPURITIES IN THE WATER

Only aluminium (approximately $0.5 \mu \mathrm{g}$ (micro-) per ml) was detected by emission spectrography.

Because the container used in the study is of a smaller volume there had to be an adjustment in thei volume and concentration of glycerol added to the packed red cells. Experiments were carried out to find the optimum final weight/volume concentration? of glycerol (Figs. 2 and 4). The red cell recovery ofo $96.1 \%$ is achieved with a final $20 \%$ weight/volume concentration of glycerol.

The rate of freezing of the cell suspension measured at various sites within the canister gives an averagen rate of cooling for the whole unit of $0.7^{\circ} \mathrm{C}$ per second. The filled container is stored in the vapouk phase of liquid nitrogen at a temperature of about? minus $150^{\circ} \mathrm{C}$. The red cells after recovery ares transfused as a packed suspension in saline with an average PCV of $75 \%$. The longest period of storage has been 21 weeks and all dcnations have been screened for the hepatitis-associated antigen before्षे being released for clinical use. 


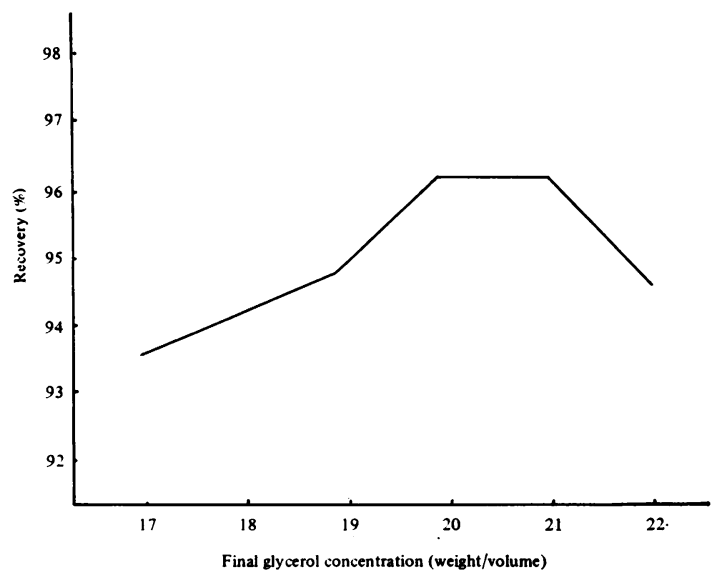

Fig. 3 The graph shows the relationship between the percentage recovery of red cells and the final glycerol concentration in $\mathrm{g}$ per $100 \mathrm{ml}$ under constant conditions of rate of freezing and recovery procedure.

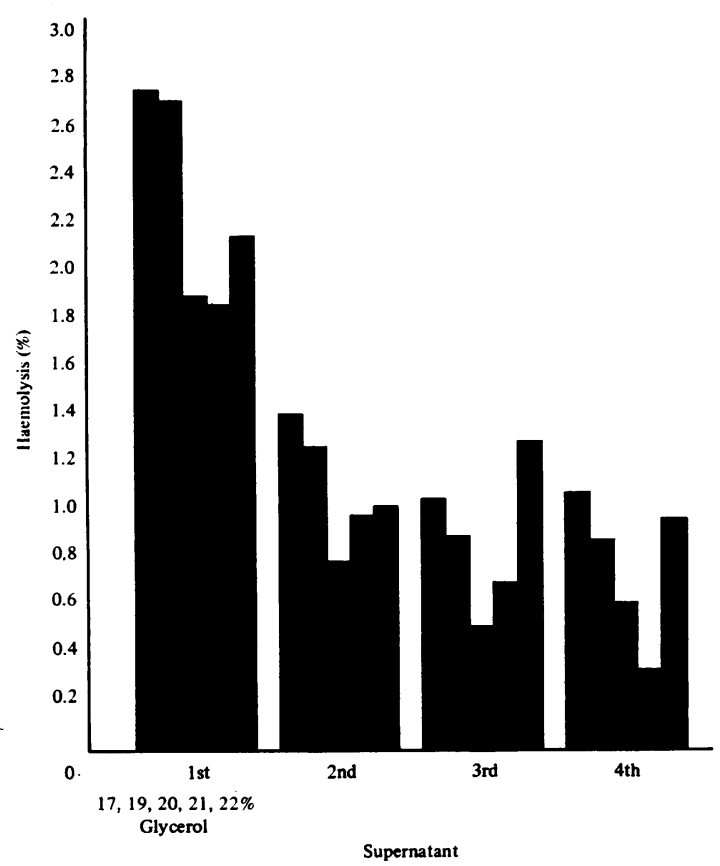

Fig. 4 The percentage haemolysis at the four stages of the recovery process for a range of glycerol concentrations between 17 and $22 \%$.

\section{Assessment of the Modifications}

IN VITRO RED CELL RECOVERY (ROBSON, 1970) The average recovery figures from 4 units which have been frozen and recovered are set out in Table I. The recovery of $96 \%$ of intact cells is identical with the figure achieved by Krijnen et al (1970).

\begin{tabular}{lc}
\hline Free Haemoglobin $(m g)$ and (as Percentage of Total Cells) \\
\hline First supernatant & $1,061(1 \cdot 8)$ \\
Second supernatant & $462(0 \cdot 83)$ \\
Third supernatant & $324(0 \cdot 58)$ \\
Fourth supernatant & $371(0.66)$ \\
Total free haemoglobin from haemolysed cells & \\
(mg) & $2,192 \mathrm{mg} \mathrm{(3.87)}$ \\
Weight of haemoglobin in cells frozen (g) & 55.6 \\
Average recovery $(\%)$ (range 94.9 to $96.5 \%)$ & 96.1
\end{tabular}

Table I Red cell recovery (in vitro) (average from 4 units)

The average of free haemoglobin per unit of packed cells transfused is $85 \mathrm{mg}$ (range 53 to $120 \mathrm{mg}$ ). Blood collected in acid-citrate-dextrose and stored at $4^{\circ} \mathrm{C}$ for 21 days has an average of $143 \mathrm{mg}$ of free haemoglobin for each unit of $420 \mathrm{ml}$.

Table II gives some biochemical and haematological data on a unit of frozen/recovered blood.

\begin{tabular}{lll}
\hline & Intracellular & Extracellular \\
\hline Sodium (m-equiv/l) & 31 & 168 \\
Potassium (m-equiv/l) & 96 & $0 \cdot 5$ \\
Haemoglobin & $50 \mathrm{~g}$ per unit & $85 \mathrm{mg}$ per unit \\
Total protein & - & Nil \\
Anti-A and anti-B & - & Not Detected \\
White blood cells & - & 550 per $\mathrm{mm}^{3}$ \\
Platelets & - & Less than 10,000 per $\mathrm{mm}^{3}$ \\
\hline
\end{tabular}

Table II Electrolyte, white blood cell, and platelet status of frozen blood (unit of frozen blood)

OSMOTIC FRAGILITY (DACIE AND LEWIS, 1968) The osmotic fragility of red cells stored at $4^{\circ} \mathrm{C}$ for 24 hours and 21 days in acid-citrate-dextrose is compared with cells recovered from liquid nitrogen (Fig. 2). The mean corpuscular fragility for the frozen/recovered cells is $0.56 \% \mathrm{NaCl}$ compared with figures of $0.50 \%$ and $0.53 \% \mathrm{NaCl}$ for acid-citratedextrose blood stored at $4{ }^{\circ} \mathrm{C}$ for 24 hours and 21 days respectively (see Table II).

RED CELL SURVIVAL

The 24-hour posttransfusion survival of frozen blood estimated by the automated Ashby technique (Szymanksi, Valeri, Almond, Emerson, and Rosenfield, 1967) shows a $92-94 \%$ survival, the curve then 


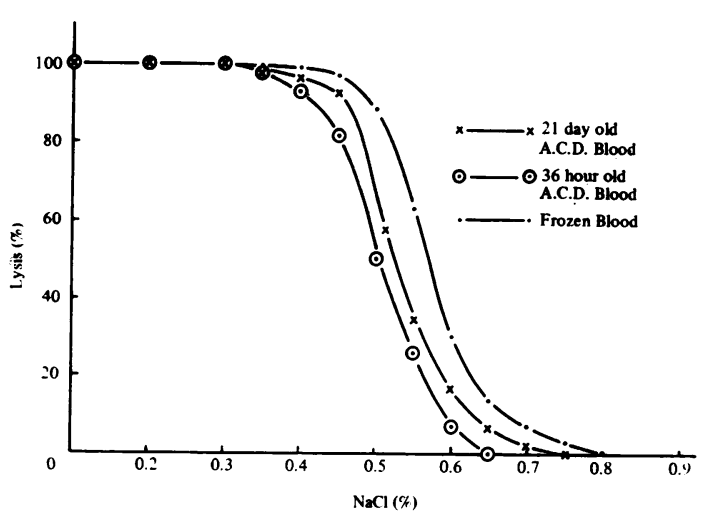

Fig. 5 Osmotic fragility of red cells stored in acidcitrate-dextrose at $4^{\circ} \mathrm{C}$ for 36 hours and 21 days, also frozen red cells after recovery.

follows that of fresh blood. The ${ }^{51} \mathrm{Cr}$ tagged cells show a $85-93 \%$ survival 24 hours after transfusion with ${ }^{51} \mathrm{CrT} \frac{1}{2}$ of 22 to 24 days.

\section{Discussion}

The establishment of a frozen blood bank according to the principles laid down by Krijnen et al (1964) has been highly successful and remarkably free of problems. The use of a one-piece aluminium container has resulted in less danger of contamination while preserving equally good recovery figures for processed red cells. Briefly, the advantages of a liquid nitrogen blood bank are: (1) to stockpile donor blood of rare cell types; (2) to stockpile donor blood of common types during periods of excess donor response to be made available during periods of donor shortage; (3) to ensure that adequate tests for the hepatitis-associated antigen are carried out before transfusion; (4) to have all the advantages of washed red cells which may be reconstituted in electrolyte or any protein solution to suit individual patients.

The disadvantages are two.

\section{$\cos T$}

The Krijnen method is probably the least expensive yet available. To set up a liquid nitrogen bank capable of storing 500 units of blood, the capital cost has been approximately $£ 2,500$ and the running costs, inclusive of labour and materials, but excluding the primary collection pack, about $£ 1.50$ per unit processed.

\section{SHELF LIFE AFTER THAWING}

The recommendation in the UK is that a container of blood once opened (punctured) should be used or discarded within 12 hours (Department of Health and Social Security, 1963).

The overall deficit of approximately $15 \%$ of the original donation of red cells (made up of a $7 \%$ processing loss and an $8 \%$ immediate posttransfusion loss) has to be considered in relation to all the advantages and to the fact that there is an equal loss shown by the 24-hour posttransfusion survival of acid-citrate-dextrose blood which has been stored for 10 days at $4^{\circ} \mathrm{C}$ (Seidle and Spielmann, 1970).

It is debatable as to how much free haemoglobin can be transfused without harm, but it should be remembered that many patients are receiving acid-citrate-dextrose banked blood which has been stored for three weeks when the total free haemoglobin may reach $140 \mathrm{mg}$ per unit transfused. Although the PCV of the red cell suspension is about $75 \%$, the cells being suspended in saline have a relatively low viscosity and are transfused without difficulty.

A number of patients receiving regular transfusions who had experienced severe pyrexial reactions remained reaction-free during transfusions of frozen blood.

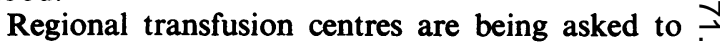
provide blood which has been tested for the presence of $\mathrm{H}-\mathrm{A}$ antigen. According to some workers, the process of freezing and recovering blood actually reduces its infectivity rate for hepatitis (Huggins, 1970; Tullis, Hinman, Sproul, and Nickerson, 1970). Many patients on renal dialysis are candidates for future renal transplants and it is desirable to keep them free of leucocyte antibodies before the transplant. Frozen blood has the advantage that the wash procedure greatly reduces the white cell count thus lessening the chances of stimulating leucoagglutinins in the patient.

Encouraged by experience to date, it is intended to set up a large bank of frozen blood to supplement the needs of hospitals during periods of donor shortage.

Three experienced technicians could recover $\rightarrow$ about 100 units per day, which would make a very useful contribution to requirements during holiday $N$ periods.

A serious limiting factor at present is the 12-hour shelf life after thawing. Attempts are being made to $\mathrm{\omega}$ develop a closed system which would allow a much longer shelf life after processing.

The authors wish to thank Dr R. Pilsworth, Director $\stackrel{\mathbb{\infty}}{\rightarrow}$ of the Public Health Laboratory Service, Chelmsford, $\frac{0}{7}$ for bacteriological investigations, the Department of $\frac{P}{\mathbb{D}}$ Health and Social Security for the analysis of $\stackrel{\square}{\mathscr{Q}}$ aluminium containers and their contents, and $\mathrm{Mr} \stackrel{\mathbb{Q}}{\mathscr{Q}}$ A. R. Joy of Oldchurch Hospital for red cell sur- 
vival studies. Considerable technical assistance was given by Mrs M. Cooper.

\section{References}

Dacie, J. W., and Lewis, S. M. (1968). Practical Haematology, 4th ed., p. 166. Churhill, London.

Department of Health and Social Security (1963). Notes on Transfusion; Issued by the Ministry of Health in Association with the Scottish Home and Health Department.

Huggins, C. E. (1970). Reversible agglomeration-a practical method for removal of glycerol from frozen blood. In Modern Problems of Blood Preservation, pp. 138-155. Fischer, Jena.

Krijnen, H. W., Wit, J. J. Fr.M. de, Kuivenhoven, A. C. J., Loos J. A., and Prins, H. K. (1964). Glycerol treated human red cells frozen with liquid nitrogen. Vox. Sang. (Basel), 9, 559-572.

Krijnen, H. W., Kuivenhoven, A. C. J., and Wit, J. J. Fr.M. de, (1970). The preservation of blood cells in the frozen state. In
Modern Problems of Blood Preservation, pp. 176-183. Fischer, Jena.

Robson, D. C. (1970). Rapid freezing and thawing techniques using extra-cellular agents. In Modern Problems of Blood Preservation. pp. 204-208. Fischer, Jena.

Rowe, A. W., Eyster, E., and Kellner, A. (1968). Liquid nitrogen preservation of red blood cells for transfusion: a low glycerolrapid freeze procedure. Cryobiology, 5, 119-128.

Seidle, S., and Spielman, W. (1970). Comparative studies on the effect of different nucleosides in red cell preservation. In Modern Problems of Blood Preservation, pp. 72-77. Fischer, Jena.

Sherwin, G. A. (1956). An infection hazard of blood collection. J. med. Lab. Technol., 13, 468-469.

Szymanski, I. O., Valeri, C. R., Almond, D. V., Emerson, C. P., and Rosenfield, R. E. (1967). Automated differential agglutination for measurement of red cell survival. Brit. J. Haemat., 13, Suppl., 50-53.

Tullis, J. C., Hinman, J., Sproul, M. T., and Nickerson, R. J. (1970). Incidence of post-transfusion hepatitis in previously frozen blood. J. Amer. med. Ass., 214, 719-723. 